\title{
HAKIKAT KEBEBASAN BEREKSPRESI DALAM PERSPEKTIF HUKUM HAK ASASI MANUSIA
}

\author{
Denindah Olivia \\ Mahasiswa pada Fakultas Hukum Universitas Padjajaran \\ Jl. Raya . Bandung Sumedang KM.21, Hegarmanah, Kec. Jatinagor, Kab. Sumedang, \\ Jawa Barat, 45363 \\ E-mail : denindah17001@mail.unpad.ac.id
}

\begin{abstract}
RINGKASAN
Pelaksanaan hak kebebasan berekspresi, tanpa adanya rasa takut atau campur tangan penting untuk eksis di tengah-tengah masyarakat yang demokratis, di mana setiap orang mendapatkan akses dalam menikmati hak asasi manusia. Sayangnya, pemerintah di berbagai negara di dunia seringkali memenjarakan orang disebabkan oleh pelaksanaan hak kebebasan berekspresi Pemerintah seringkali melarang penyampaian pidato yang mangandung ujaran kebencian, namun juga kedapatan melakukan penyalahgunaan wewenang mereka untuk membungkam keberagaman pendapat dari warganya, serta mengeluarkan regulasi (peraturan perundang-undangan) yang mengkriminalisasi kebebasan berekspresi belakangan ini. Kebebasan berekspresi sedang berada dalam krisis dikarenakan perlindungannya terancam oleh adanya pihak berwenang yang bersifat represif terhadap aktivis, LSM serta individu yang kritis. Tulisan ini akan menganalisis hak kebebasan berekspresi sebagai suatu hak asasi manusia yang penegakkannya perlu untuk diperkuat di era modern dewasa ini.
\end{abstract}

Kata kunci : demokratis, hak asasi manusia, hak kebebasan ekspresi, regulasi, pemerintah.

\section{PENDAHULUAN}

Kebebasan berekspresi memiliki sejarah yang sangat panjang, terbentuk dari perkembangan politik, ekonomi, dan sangat terpengaruh dari perubahan teknologi, dimulai dari penemuan mesin cetak sampai siaran radio kepada teknologi digital. Dengan pesatnya perubahan gelombang dalam kerangka komunikasi dan layanan, kemudian muncul isu-isu terkait sebagai bagaimana cara terbaik untuk mengartikulasi nilai kebebasan berekspresi dan melindungi tiap individu dari pembatasan hak atas kebebasan berskpresi yang tidak wajar. Tantangan untuk kebebasan berekspresi bukan merupakan hal yang baru, namun hal tersebut sering terjadi disekitaran kita. Seperti contoh yang sangat terkenal adalah adanya kasus ujaran kebencian (Daniel Emlyn-Jones dan ) yang menyangkut keluhan terkait komentar yang diposting di suatu situs web berkaitan dengan komentar terkait komunitas Lesbian, Gay, Bisexual, dan Transeksual ("LGBTQ") oleh individuindividu, namun The President of The Discrimination Tribunal menyatakan bahwa Canberra Times tidak serta merta bertanggung jawab karena publikasi dibuat secara wajar dan jujur untuk keperluan kepentingan umum. ${ }^{1}$ Begitu

\footnotetext{
1 Factsheet of Right to Freedom of Expression, Human Rights and Discrimination CommissionerACT Human Rights Commission. Dapat diakses melalui https://hrc.act.gov.au/wpcontent/uploads/2015/03/Section-16-Right-toFreedom-of-Expression.pdf
} 
berkembangnya isu-isu dibidang HAM terutama hak kebebasan berekspresi menyebabkan perlu adanya pemahaman yang menyeluruh berkaitan dengan hak kebebasan berekspresi. Pemahaman ini amat sangat penting, dikarenakan setiap individu mengemban hak asasi manusia yang sama diseluruh dunia, terlepas dari latar belakang agama, etnis, ras, ekonomi, sosial, dan budaya yang juga diiringi oleh kewajiban yang terkait (yang seringkali juga sama pentingnya). ${ }^{2}$

Cakupan dari hak kebebasan berekspresi terdiri dari dua argumen kuat. Argumen pertama adalah kebabasan merupakan prasyarat penting bagi keberlangsungan hidup demokrasi. Perlindungan perlu untuk diberikan terhadap kebebasan berekspresi terhadap masyarakat dan perberlakuannya perlu dilindungi oleh negara yang representatif. Argumen kedua yakni bahwa kebebasan tersebut perlu untuk memberikan perlindungan terhadap individu sebagai sebuah entitas yang bebas dan merdeka serta tidak terbelenggu oleh tirani keotoriteriatan. Kebebasan berekspresi secara universal dikenal sebagai hak asasi manusia yang fundamental, tidak hanya sebagai dasar landasan demokrasi, namun juga sangat relevan terhadap kehidupan masyarakat sipil dalam suatu negara. ${ }^{3}$ Bahkan ada argumen yang menyatakan bahwa kebebasan berkespresi merupakan hak asasi manusia yang paling penting. ${ }^{4}$

Hak kebebasan berekspresi dilindungi oleh berbagai kovenan regional maupun internasional. ${ }^{5}$ Apabila mengacu pada Pasal 19 ayat (2) dari

\footnotetext{
2 Foreword oleh Mary Robinson, Perserikatan Bangsa-Bangsa dalam Human Rights- A Basic Handbook for UN Staff.

3 UN General Assembly, Resolution 59 (1), 14 Desember 1946.

${ }^{4}$ Centre for Law and Democracy, Pembatasan Kebebasan Berekspresi : Sebuah Standar dan Prinsip, Latar Belakang Pertemuan yang diselenggarakan oleh UN Special Reporteur tentang Freedom of Opinion and Expression.

${ }^{5}$ Lihat contoh, Konvensi Eropa tentang Hak Asasi Manusia, Artikel 10 : Konvensi Amerika tentang Hak Asasi Manusia.
}

Kovenan Internasional tentang Hak-Hak Sipil dan Politik (ICCPR), sebuah kovenan yang mengikat secara hukum dan telah di ratifikasi oleh 165 negara yang berfokus mengenai hak asasi manusia yang pada intinya menyatakan bahwa setiap orang berhak untuk mengakses kebebasan berpendapat, yang termasuk kedalam nya adalah kebebasan mencari, menerima, dan memberikan informasi dan pemikiran apapun. ${ }^{6}$

Tinjauan akan hak untuk berekspresi kian dilakukan oleh sarjana hukum sebagai hak kodrati dari manusia. Maupun itu dari segi psikologis, fisiologis, atau yuridisnya, permasalahan ekspresi akan tetap dijaga sebagai tonggak Hak Asasi Manusia primer. Pembahasan dari Hak Asasi Manusia, lebih khususnya pada pembahasan kebebasan berekspresi, telah berevolusi pada hal-hal yang lebih khusus dan refined. Sama hal-nya yang sempat disinggung diatas, akan hak-hak kebebeasan berkspresi komunitas LGBTQ. Ada banyak pula hak komunitaskomunitas yang belum secara holistic dikaji oleh para sarjana hukum, seperti halnya hak kebebasan berekspresi penganut kepercayaan pecahan dari agama islam (Islam Ahmadiyah) atau bahkan kebebasan berekspresi sukusuku yang dianggap melanggar standar hukum negaranya. Perlunya dilakukan suatu kajian dalam sub-kategori ini, dikarenakan kekebasan berekspresi limitasinya terkadang tidak jelas dan bergantung pada undang-undang tiaptiap negara.

\section{PERMASALAHAN}

Bagaimana Hakikat Kebebasan Berekspresi Dalam Perspektif Hukum Hak Asasi Manusia?

PEMBAHASAN Hak kebebasan berekspresi merupakan salah satu hak asasi manusia. Hak tersebut bersifat

\footnotetext{
${ }^{6}$ Kovenan Internasional tentang Hak-Hak Sipil dan Politik, 16 Desember 1966, Perserikatan Bangsa-Bangsa, Treaty Series, Vol. 999, HIm, 171.
} 
sangat mendasar atau fundamental sehingga tidak ada instrumen maupun kuasa yang dapat mengapuskannya. ${ }^{7}$ Sebagaimana dikemukakan oleh Locke, bahwa hak asasi manusia merupakan hak-hak yang diberikan oleh Tuhan secara langsung sebagai hak kodrati (natural rights theory). Manusia mengemban hak tersebut semata-mata karena martabatnya sebagai seorang manusia, bukan karena hadiah penguasa maupun hukum positif suatu negara. ${ }^{8}$ Adapun sifat dari hak asasi manusia yang dianugerahi oleh Tuhan tersebut merupakan refleksi atas kodrat manusia yang berbeda dan tidak berubah, maka dari itu hukum alam adalah merupakan hukum alam manusia. ${ }^{9}$

Senada dengan pendapat diatas berkaitan dengan hak asasi manusia, yakni hak moral yang dimiliki oleh semua orang terlepas dari keanggotaanya dalam politik tertentu, ras, etnis, agama, atau kelompok sosial lainnya. ${ }^{10}$ Singkatnya, hak asasi manusia adalah hak moral yang dapat secara sah dilaksanakan oleh siapa saja, kapan saja, atau di mana saja.

Hak asasi manusia sebagai hak moral melekat kewajiban terhadap orang lain. Kewajiban tersebut dapat berupa kewajiban negatif, yakni kewajiban untuk tidak menghambat kebebasan yang dilindungi oleh hak moral atau yang mengancam nyawa sebagai contoh. Sebagai alternatif, kewajiban dapat pula berupa kewajiban positif yang memerlukan mereka sebagai subjek

\footnotetext{
7 Masyhur Effendi, Dimensi dan Dinamika Hak Asasi Manusia dalam Hukum Nasional dan Internasional, 1994, Jakarta : Ghalia Indonesia, hlm. 3.

8 Jack Donnely, Universal Human Rights in Theory and Practice, 2003, Cornell University Press, Itchaca and London, hlm. 7

${ }^{9}$ Alexander Hamilton, The Farmer Refuted, dalam Henry Cabot Lodge, ed., The Works of Alexander Hamilton (New York: G.P. Putnam's Sons, 1904) Volume. 1, hlm. 113

10 Allen Buchanan dan David Golove, The Philosophy of International Law, dalam Oxford Handbook of Jurisprudence and Philosophy Law, oleh J. Coleman, 2002, hlm. 867
}

untuk melakukan sesuatu sebagai perwujudan pemenuhan hak tersebut. Adapun kebebasan berekspresi biasanya dianggap sebagai perwujudan kewajiban negative bahwa pemerintah tidak dapat memberi penghukuman terhadap kebebasan tertentu. Namun demikian, hak kebebasan berekspresi kadangkadang dianggap menempatkan kewajiban negatif pada setidaknya beberapa aktor non pemerintah pula. ${ }^{11}$ Bahkan terkadang dijadikan pendukung kewajiban positif yang dibebankan kepada pemerintah untuk memberi sarana dan kapasitas bagi individu mengekspresikan dirinya. ${ }^{12}$

Penulis akan mengutip pendapat demokrasi oleh Alexander Meiklejohn. ${ }^{13}$ Beliau menyatakan bahwa demokrasi merupakan suatu konsekuensi logis dari adanya kontrak sosial yang terkandung dalam konstitusi, serta kebebasan berpendapat merupakan prasyarat dari pemerintahan yang demokratis. Dari premis pemerintahan "demokratis" yang diatur dalam konstitusi kita, hak kebebasan berbicara dideduksi. Apabila negara ingin bertindak secara demoktratis, maka rakyat harus memiliki kesempatan untuk merumuskan pandangan tentang hal-hal yang penting bagi publik serta untuk mengekspresikan pandangan tersebut kepada perwakilan rakyat yang secara demokratis pula dipilih oleh rakyat.

Adapun pendapat terbaru berikaitan dengan demokrasi adalah sebagaimana dikeukakan oleh John Hart Ely dalam bukunya Democracy and Distrust. ${ }^{14}$ Beliau tidak sependapat dengan Meiklejohn bahwa interpretasi beliau berikatan dengan pembatasan hak melibatkan ketidak tepatan penyeimbangan konflik kepentingan. Namun, beliau mengakui bahwa adanya penetapan dasar kebebasan yang

\footnotetext{
11 ibid. hlm. 888.

12 Owen M. Fiss, Free Speech and Social Structure, 71 Iowa L. Rev 1405 (1986), Cass R Sunstein, Free Speech Now, 59 I. Chi. L. Rev. 255 (1992)

${ }^{13}$ A. Meiklejohn, Political Freedom 1965

14 J.H. Ely, Democracy and Distrust (1980)
} 
demokratis akan memberikan gagasan yang lebih baik tentang ruang lingkup dan bobot yang perlu dilekatkan padanya ketika terjadi konflik dengan kepentingan lain.

Adapun, Ely berpendapat bahwa demokrasi menawarkan pembenaran untuk perlindungan kebebasan untuk melawan tindakan pemerintah yang opresif dan sewenang-wenang dan sebagai perlindungan hukum dalam berperkara di pengadilan. Beliau juga berpendapat bahwa hak untuk kebebasan berbicara tidak bertentangan dengan prinsip -prinsip pemerintahan yang menerapkan adanya perwakilan rakyat dan pemerintah mayoritas. Apabila pemerintah perlu untuk responsif terhadap kepentingan warganya, maka warga negaranya perlu diakomodasi dalam penyampaian masalah-masalah politik dan disediakan wadah untuk berkomunikasi dengan perwakilan politik mereka. Interpretasi beliau berkaitan dengan demokrasi tentang kebebasan menawarkan dasar nilai yang netral dalam tinjauan yudisial atas tindakan pemerintah dan hal tersebut menawarkan hak kebebasan berbicara dengan prinsip kekuasaan mayoritas. Adapun tuntutan perwakilan memberikan pembenaran dan standar untuk intervensi peradilan.

Namun apakah ide demokrasi dapat memberikan premis di mana kita dapat menyimpulkan apa saja jenis-jenis "ekspresi" yang harus dilindungi? Hak untuk memilih dalam pemilihan umum saja tidak cukup dalam mencerminkan negara yang demokratis, meskipun sering dikaitkan. Dalam sebuah pemerintahan yang representatif, warga negaranya harus mampu untuk berkomunikasi dengan calon legislatif atau calon eksekutif dalam negaranya. Namun apakah perwujudan "representatif" memerlukan lebih dari hanya sekedar ini? Apakah perwujudan demokrasi juga memperbolehkan warga negara untuk dapat bertukar informasi dan gagasan tentang masalah-masalah politik dan moral, sebagaimana yang diyakini oleh Meiklejohn dan Ely? Invididu yang terbiasa menerima berbagai macam ide dan informasi akan memiliki pengetahuan akan informasi danpandangan yang lebih luas. Meiklejohn memasukan pidato, literatur, filsafat, sains dan seni rupa yang berkontribusi pada perkembangan nilainilai kemanusian dapat dilindungi dan merupakan ekspresi sehingga perlu perlindungan kebebebasannya.

Teori demokrasi mengenal bahwa kebebasan berekspresi dan pemerintahan yang representatif saling berkaitan, namun nampaknya terdapat kesalahpahaman berkaitan dengan hubungannya. Keterkaitan keduanya adalah kebebasan berekspresi dan pemerintahan yang representatif memberikan kemajuan dalam kapasitas individual dan cara hidup tertentu dalam kerangka kebebasan manusia yang pada hakikatnya bebas dan merdeka. ${ }^{15}$ Dibawah pemerintahan yang 'representatif', individual diperkenankan untuk menentukan sendiri kepentingan masing-masing dan untuk memberikan pandangan mereka sendiri. Seorang individu yang membuat pandangan sendiri dan yang berpartisipasi dalam pemerintahan akan berkembang sebagai individu yang cerdas dan peka terhadap nilai-nilai. Demikian pula individu yang melaksanakan hak nya dalam kebebasan berekspresi, dalam berbagai bentuk bahkan dalam berwarga negara akan berkembang menjadi manusia yang berpikir kritis.

Namun teori ini memiliki kelemahan. Hal ini tercerminkan sebagai berikut : apabila teori tersebut berkaitan dengan persyaratan dari pemerintahan yang representatif, maka teori tersebut tidak dapat menjelaskan berkaitan dengan 'ekspresi' yang dilindungi oleh teori tersebut. Teori tersebut tidak dapat membenarkan ekspresi artistikmaupun

15 Nadia Urbinati, Condorcet's Democratic Theory of Representative Government, January 1 2004, European Journal of Political Theory, Volume 3, Issue 1 
diskusi politik diantara warga negara. Apabila fokus daripada teori ini diperluas dari persyaratan perwakilan politik memungkinkan adanya cakupan perlindungan hak yang lebih luas. Namun, kemudian esensi dari teori tersebut yakni proses politik menjadi individu sehingga bukan lagi menjadi teori demokratis melainkan teori tentang hak individu.

Namun sekarang perlindungan hak kebebasan berekspresi telah dilindungi secara konstitusional. Kebebasan tersebut tidak perlu lagi dibenarkan sebagai prasyarat dari negara yang demokratis. Nilai-nilai yang mendasari kebebasan tidak boleh lagi dikemas dalam nilai pemerintahan yang representatif. Sampailah Penulis pada pendapat kunci yang dikemukakan oleh John Locke bahwasanya kebebasan berekspresi adalah cara untuk mencari kebenaran. Kebebasan berbicara ini diletakkan sebagai kebebasan dalam mencari, menyebarluaskan serta menerima informasi lalu kemudian mendiskusikannya dengan individu lain sebagai sebuah proses dalam mengeliminasi keragu-raguan. ${ }^{16}$ Kemudian John Stuart berpendapat bahwa kebebasan berekspresi penting guna melindungi warga dari penguasa yang sewenang-wenang. ${ }^{17}$ Maka dari itu, pemerintahan yang menganut demokrasi memiliki syarat bahwa warganya memiliki ruang untuk menyampaikan kritikan atas kinerjanya. Dalam kontrol tersebutlah perlu adanya transparansi informasi dan warga memiliki akses terhadap penyampaian dan penerimaan informasi, sehingga dapat memperbincangkannya dengan individu lainnya. ${ }^{18}$

\section{Ekspresi: Suatu Etimologi}

\footnotetext{
16 Larry Alexander, Is There a Right to Freedom of Expression, New York : Cambridge University Press, 2005 hlm 128

17 John Stuart Mill, On Liberty, Chapter II, of The Liberty on Thought and Discussion, 1859.

18 Larry Alexander, op. cit. hlm 136
}

Hematnya, menurut Kamus Besar Bahasa Indonesia, Ekspresi merupakan pengungkapan atau proses pengungkapan ide, gagasan, perasaan dari seorang individu atau, juga bisa dikatakan sebagai pandangan muka yang memperlihatkan perasaan atau keadaan emosional seseorang. ${ }^{19}$ Sistematika pengertian yang diungkapkan oleh Kamus Besar Bahas Indonesia memperlihatkan dua hal yang saling menyandingin berkaitan dengan pengertian kata 'ekspresi'. Yakni, suatu proses dan suatu ungkapan fisiologis. Keduanya merupakan refleksi dari sifat dasar manusia.

Sifat dasar dari manusia tersebut digarisbawahi dan didiskusikan oleh Wolfgang Kohler, dimana ia menyatakan bahwa, disamping dan beriringan dengan bahasa, ekspresi merupakan suatu hal yang esensial dan imperative dalam pengalaman suatu insan (an essential and imperative segment of the human experience)..$^{20}$ Wolfgang Kohler melanjutkan apa yang dikatakan oleh Shanker dan King, menitikberatkan bahwa komunikasi melewati aksara atau berbicara, maupun itu ekspresi atau bahasan, merupakan eksternalisasi dari pengalaman internal suatu manusia yang menjadi respon terhadap kejadian atau stimulasi dari dunia luar. Eksternalisasi tersebut disebutnya sebagai penting, dikarenakan hal tersebut merupakan korolary yang niscaya ada terhadap proses internalisasi yang ada karena stimulant dari dunia luar. ${ }^{21}$ Bisa disimpulkan dari sifat etimologi dan ilmiah dari suatu ekspresi, bahwa ekspresi adalah suatu hal yang amat sangat mendasar dari bagian seorang

19 Kementrian Pendidikan dan Kebudayaan Negara Republik Indonesia, "Kamus Besar Bahasa Indonesia" (Jakarta: Kemendikbud ,2018), hlm. 291.

20 Yves Visetti \& Victor Rosenthal, 'Human Expression and Experience: What does it mean to have Language?',25 Behavioral and Brain Sciences 05 (2002), hlm. 643 - 644.

${ }^{21}$ Jerome Bruner, 'The Narrative Construction of Reality', Critical Inquiry (1991), hlm. 4. 
manusia. Sejatinya dari sub-bab ini, penulis ingin menyimpulkan dari kutipan Wolfgang Kohler, bahwasanya untuk membatasi (sepenuhnya atau sebagian) ekspresi manusia, merupakan suatu keloliman yang hakiki.

\section{Hukum Hak Asasi Manusia Internasional}

Piagam Perserikatan Bangsa-Bangsa, sebagai 'konstitusi masyarakat internasional', mempromosikan suatu rasa hormat mutual dan perhatian pada hak asasi manusia dan kebebasan fundamental lain tanpa membedakan masyarakat berdasarkan ras, gender, bahasa, atau agama sekalipun. Majelis Umum Perserikatan Bangsa-Bangsa mengulangi tanggung jawab ini pada tahun 1948 yang mengafirmasikan proteksi universal terhadap hak asasi dan kebebasan manusia yang fundamental. Afirmasi ulang tersebut biasa disebut sebagai Deklarasi Universal Hak Asasi Manusia ("DUHAM") atau Resolusi Majelis Umum Perserikatan Bangsa-Bangsa No. 217(A) III. Melihat perkembangan sejarah dan hukum internasional secara keseluruhan, Tayyana Eatwell mengkategorikan 4 (empat) sumber hukum hak asasi manusia internasional. Yakni, (1) dua konvensi yang bersifat universal bernama Kovenan Internasional Tentang Hak Sipil dan Politik tahun 1966 dan Konvensi Internasional Tentang Hak Ekonomi, Sosial dan Budaya tahun 1966. (2) Konvensi-Konvensi Regional seperti Konvensi Tentang Hak Asasi dan Kebebasan Fundamental Manusia Benua Eropa. (3) Konvensi yang mencakupi hak-hak spesifik seperti Konvensi melawan Penyiksaan dan Perlakuan tidak Manusiawi Lainnya tahun 1984. (4) Terakhir, Konvensi yang mencakupi hakhak pada kelompok manusia spesifik, seperti Konvensi Hak untuk Anak tahun 1989.22

22 Paul Sieghart, "The International Law of Human Rights" (Oxford: Clarendon Press, 1983), hlm. 11.
Dalam hal-nya kebebasan berekspresi, dipersoalkannya kebebasan tersebut dapat dilihat di DUHAM. Lebih jelasnya pada Pasal 19, Kebebasan untuk berekspresi digabungkan dan tampaknya menjadi suatu keniscayaan dari kebebasan beropini (hak mengeluarkan pendapat), sekaligus untuk mencari, menerima, dan memilah informasi dan ide melalui segala media terlepas dari tempat kedudukan apapun. Selanjutnya

\section{Teori Tanggung Jawab Negara}

Tanggung jawab negara dibawah Hukum Hak Asasi Manusia Internasional dapat dibagi menjadi 2 kategori: kewajiban positif dan kewajiban negatif. Terminologi 'positif' dan 'negatif' tidak dipakai untuk mengimplikasikan penilaian apapun dari tiap-tiap tanggung jawab. Melainkan, terminologi tersebut dipakai untuk mendiferensiasikan kewajiban dimana suatu negara tidak boleh melakukan sesuatu atau tidak boleh berperilaku dalam dalam suatu pola tertentu (kewajiban negatif), dan kewajiban untuk berperilaku atau melakukan - mengambil langkah-langkah positif - untuk mengimplementasikan aturan untuk menjamin perlindungan hak individu dari pelanggaran hak-hak tersebut oleh organ negara dan oleh pelaku-pelaku swasta (kewajiban positif). ${ }^{23}$

Sebagaimana disebutkan oleh Komisioner Tinggi Perserikatan BangsaBangsa untuk Hak Asasi Manusia (United Nations High Commissioner for Human Rights), "semua bagian dari masyarakat manusia memiliki hak dan kewajiban dibawah hukum hak asasi manusia. Negara mengemban tanggung jawab utama, bukan hanya untuk menghormati hak asasi mausia dan merespon pada pelanggaran-pelanggaran yang mungkin dapat terjadi, tapi negara juga memiliki

\footnotetext{
23 Tatyana Eatwell, 'State Responsibility for Human Rights Violations Commited in the State's Territory by Armed Non-State Actors', The Academy a Joint Center of University of Geneva and the Graduate Institute of Geneva: Academy Briefing No. 13, hlm. 43.
} 
tanggung jawab untuk memberikan perlindungan bagi para pihak dari pihak ketiga dan untuk membuat suatu lingkungan dimana semua hak itu dihormati sebagaimana mestinya. Selagi, diambil sebagai contoh, pelaku pemegang senjata, pemilik tanah, dan pelaku bisnis harus menghormati semua hak asasi manusia dan harus dijadikan akuntabel terhadap semua pelanggaran yang mereka lakukan, Negara melalui kebijakan dan/atau aturannya, program kerjanya, dan hukumnya harus bertindak guna menghentikan terjadinya pelanggaran ini dan menghentikan pengulangan dari pelanggaran tersebut." 24 Namun ini memberikan ruangan untuk negara, sejalan dengan konstitusinya, untuk menentukan haluan dari kebebasan berekspresi tersebut.

\section{Yurisdiksi Negara Terhadap Perlindungan Hak Asasi Manusia}

Yurisdiksi negara dalam halnya penegakan hak asasi manusia disinggung dalam Pasal 2 dari Kovenan Internasional Tentang Hak Sipil dan Politik Tahun 1966 ("ICCPR 1966"). Dalam pasal tersebut dijelaskan bahwa suatu negara berkewajiban untuk menghormati dan menjamin hak asasi manusia di wilayah kekuasaannya atau kepada subjek-subjek yang berada dibawah yurisdiksinya. ${ }^{25}$ Dari redaksi tersebut dapat disimpulkan bahwa ada unsur kesengajaan dari pihak pembuat (drafter) ICCPR 1966 untuk membuka peluang jikalau adanya yurisdiksi negara

24 Komisi Perserikatan Bangsa-Bangsa untuk Melawan Tindakan Penyiksaan, Laporan Konsideran Diajukan oleh Negara Anggota dibawah Pasal 19 dari Konvensi Melawan Penyiksaan: Kesimpulan dan Rekomendasi dari Komite melawan Penyiksaan, Sesi ke-36, 1-19 May 2006, Paragraf 6, Dokumen Perserikatan BangsaBangsa CAT/C/USA/CO/2.

25 Gerald L. Neuman, 'Understanding Global Due Process', 23 Geography Immigration Law Journal 365 (2009), hlm. 819; Jacco Bomhoff, 'The Reach of Rights: "the Foreign" and "the Private" in Conflict of Laws, State Action, and Fundamental Rights Cases with Foreign Elements', 71 Law and Contemporary Problems 39 (2008), hlm. 334. yang diluar teritorinya, berlaku pada individu-individu yang berada dibawah kuasanya. ${ }^{26}$ Oleh karena itu di paragraph-paragraf berikutnya, penulis akan mencoba untuk mendefinisikan konsep yurisdiksi hak asasi manusia internasiona bagi negara-negara yang bersangkutan.

Yurisdiksi, dalam konteks hukum hak asasi manusia, pernah disinggung dalam Opini Penasehat yang dikeluarkan oleh Mahkamah Internasional tentang Tembok Palestina (Advisory Opinion on the Legal Consequences of the Construction of a Wall in the Occupied Palestinian Territory). Dimana, Israel membuat suatu tembok yang membatasi dan (secara sengaja) memotong wilayah Palestina. Ini berujung pada suatu tuduhan pelanggaran hak asasi manusia, dikarenakan terpisahnya beberapa keluarga warga negara dari keseluruhan Palestina dan terpotongnya sumber air yang menjadi hak asasi bagi wargawarga yang bertempat tinggal di Palestina. Sebagai landasan opini Mahkamah Internasional, Mahkamah pun mengatakan bahwa kasus ini merupakan suatu kasus yang unik dikarenakan keadaan yang dihadapi oleh kedua negara yang bersangkutan. Adanya ketegangan antara kedua negara tersebut harus di perhatikan guna untuk melakukan pembedaan antara Hukum Hak Asasi Manusia (human rights law) dan Hukum Humaniter Internasional (International Human Rights Law). Namun, Mahkamah Internasional melanjutkan bahwa untuk mengaplikasikan dan menjamin berjalannya instrument hukum hak asasi manusia adalah sebuah keniscayaan dalam keadaan perang sekalipun.

Sebagai simpulan dari konteks diatas, Mahkamah Internasional beropini bahwa ICCPR 1966, sekaligus dengan 2 (dua) instrument hukum hak asasi

26 Oona A. Hathaway \& Phillip Levits, 'Human Rights Abroad: When Do Human Rights Treaty Obligations Apply Extraterritorially?', 01 Arizona State Law Journal 01 (2011), hlm. 12. 
manusia internasional, dapat diaplikasikan diluar teritori suatu negara. ${ }^{27}$ Menimbang bahwa, tidak semua negara yang berandil dalam maslahat orang banyak hanya berandil pada kepentingan warga negara yang berada di teritorinya saja. Dalam kasus ini, Mahkamah internasional juga menimbang bahwa kekuatan militer dari Israel dalam memberlakukan peraturan dan membangun tembok yang memotong (yang pada akhirnya juga melanggar hak asasi dari warga Palestina) wilayah Palestina juga merupakan unjuk kekuatan dari Israel berkenaan dengan yurisdiksinya sebagai negara anggota dari ICCPR 1966.

Simpulan dari sub-bab ini, dengan juga menelaah opini dari Mahkamah Internasional, adalah negara berwenang dan bertanggung jawab terhadap menghormati dan menegakkan hak asasi manusia di dua keadaan. Pertama, dimana keadaan individu yang perlu dihormati hak-haknya berada dalam wilayah negara yang bersangkutan, ini merupakan suatu hal yang absolut dan tidak dapat diganggu gugat oleh negara lain. ${ }^{28}$ Kedua dan terakhir, keadaan dimana suatu negara dapat mementaskan kekuatannya dan menghasilkan individu-individu yang berada diluar wilayah negaranya untuk jatuh ke dalam kekuasaan atau yurisdiksinya (extra-territorial application of international human rights instruments).

\subsection{Uji Kelayakan Terhadap} Perlindungan Hak Asasi Manusia

Uji kelayakan atau due diligence merupakan suatu prinsip hukum secara umum, yang dijadikan salah satu sumber

27 Joseph Sinchak, 'The Extraterritorial Application of Human Rights Treaties: Al-Skeini et. al. v. the United Kingdom (2011)', 03 Pace International Law Review 416 (2013), hlm. 420.

28 Natasa Mavronicola, 'What is an 'absolute right'?: Deciphering Absoluteness in the Context of Article 3 of the European Convention on Human Rights', 12 Human Rights Law Review 04 (2012), published by Oxford University Press, hlm. 727. hukum internasional primer dalam Statuta Mahkamah Internasional tahun 1948. ${ }^{29}$ Secara umum, uji kelayakan merupakan suatu hal yang diperbuat oleh iuris atau praktisi untuk memastikan bahwa seseorang yang akan melakukan perbuatan hukum, dalam perbuatannya tidak menimbulkan suatu peristiwa atau implikasi hukum yang negative kepada dirinya sendiri atau orang lain. ${ }^{30}$ Dalam konteks hukum internasional, yang dalam tulisan ini dikhususkan pada hukum hak asasi manusia, uji kelayakan merupakan penjelmaan dari tanggung jawab suatu negara terhadap penegakkan dan penjaminan hak asasi dari warganya atau orang-orang yang berada dalam kekuasaan atau yurisdiksinya. ${ }^{31} \mathrm{Uji}$ kelayakan dilakukan sebagai langkahlangkah praktis bagi para penguasa negara untuk menjaminnya adanya rasa hormat bagi hak asasi manusia secara keseluruhan.

Banyak sarjana hukum yang menyatakan bahwa cara uji ketangkasan berada dalam banyak cara dan metode. Namun, Komisioner Tinggi Perserikatan Bangsa-Bangsa dalam Hak Asasi Manusia menyatakan secara garis besar ada 3 (tiga) langkah dalam pengaplikasian uji kelayakan. Pertama, merupakan menghormati adanya hak asasi manusia dan hak-hak yang harus diperhatikan oleh para penguasa terhadap konstituennya (respect). Langkah ini merupakan langkah preventif untuk menghindari adanya kejatuhan dari penjaminan hak asasi di suatu negara (contoh: edukasi mengenai hak asasi manusia kepada murid atau mahasiswa).

\footnotetext{
29 Pasal 38 Ayat (1), Statuta Mahkamah Internasional (Statute of the International Court of Justice

30 Sven de Cleyn \& Johan Braet, 'The Due Diligence Process - Guiding Principles for Early Stage Innovative Products', Prinstraat Universiteit Antwerpen BE-3000, hlm. 6.

31 Christina M. Cena, 'The Extraterritorial Scope of Human Rights Treaties: The American Convention on Human Rights', 01 American Journal of International Law 03, hlm. 23.
} 
Kedua, adanya perlindungan yang diberikan oleh negara-negara melewati undang-undang atau peraturan yang berkekuatan hukum terhadap hak-hak asasi warga negara dan konstituennya, maupun itu berada dalam atau diluar wilayah negara yang bersangkutan (protect). Langkah kedua ini merupakan konkritisasi dari langkah pertama, dimana langkah ini menyandingi suatu hal yang represif terhadap langkah preventif yang disebutkan sebelumnya, guna untuk menjamin secara keras dan eksplisit bahwa hak-hak warga negara merupakan bagian dari hukum yang mengatur jalannya negara (contoh: Pasal 28A-28J dari Undang-Undang Dasar Negara Republik Indonesia 1945 dan Undang-Undang Negara Republik Indonesia Nomor 39 Tahun 1999 tentang Hak Asasi Manusia). ${ }^{32}$

Langkah ketiga dan terakhir sengaja dipisahkan dari paragraph sebelumnya, dikarenakan sifat temporal dan situasional yang berbeda dengan langkah-langkah sebelumnya. Perbedaan berada pada hak asasi manusia yang keadaannya sudah terlanggar atau dilanggar pada langkah ketiga ini. ${ }^{33}$ Dimana langkah ketiga dari uji kelayakan hak asasi manusia mewajibkan negaranegara untuk memberikan jalan keluar hukum atau kepuasan bagi pihak-pihak yang dilanggar hak asasinya oleh apparat pemerintah atau badan-badan yang terkait (remedy). Kepuasan dan jalan keluar tersebut dapat diadakan dalam berbagai bentuk, salah satunya reparasi moneter yang dilakukan oleh suatu negara kepada warga negaranya, ataupun restitusi secara hukum, untuk mengembalikan keadaan hukum

32 Coopération Internationale Pour Le Développement Et La Solidarité, 'Human Rights Due Diligence: Policy Measures For Effective Implementation', Coopération Internationale Pour Le Développement Et $\mathrm{La}$ Solidarité Reccomendations (2011), Hlm. 5.

33 United Nations Human Rights Office Of The High Commissioner, 'The Core International Human Rights Treaties', (New York Dan Jenewa: Perserikatan Bangsa-Bangsa, 2014), Hlm. 211. sebagaimana belum terjadinya suatu pelanggaran dari hak asasi warga negara. $^{34}$

3.6. Kewajiban Indonesia Dalam Menegakkan Kebebasan Berekspresi Menurut UUD 1945

Adapun negara memiliki kewajiban untuk melindungi hak asasi manusia dari pelanggaran yang dapat timbul dari individu maupun kelompok lainnya. Bahkan, pelanggaran hak asasi manusia yang dilakukan oleh non-state actors yakni pelaku-pelaku suatu perbuatan hukum yang bukan berasal dan bukan dimandatkan oleh negara. Hak kebebasan berekspresi merupakan suatu sub-seksi yang dapat ditemukan di setiap konstitusi atau undang-undang dasar dari tiap negara demokratis. Di Amerika, the first amendment. Di Indonesia, Pasal 28E Ayat (3) Undang-Undang Dasar Negara Republik Indonesia Tahun 1945 (“UUD 1945").

Sekarang, dengan memindahkan focus kepada perlindungan konstitusional daripada hak kebebasan berekspresi yang termuat dalam UUD 1945, kita dapat melihat bahwa kebebasan berekspresi tidak secara eksplisit disebutkan dalam Pasal 28E. Namun, terdapat suatu singgungan terhadap hak tersebut yang menjadi bagian dari hak untuk mengeluarkan pendapat atau, dapat dibilang sebagai suatu hak yang mengenkapsulasikan hak-hak lain dalam Pasal tersebut. Sesuai dengan kategorisasi internasional, hak kebebasan berskpresi merupakan bagian dari hak sipil dan politik tiap individu. Oleh karena itu, dapat penulis simpulkan juga bahwa Pasal 28E yang disebutkan dalam UUD 1945 merupakan hak sipil dan politik dari Warga Negara Indonesia.

Tentu, hak merupakan suatu keniscayaan dengan penyandingnya yakni kewajiban. Dalam Pasal 28J UUD

\footnotetext{
34 Surya Deva, 'Access To Justice And Remedies For Victims Of Violations And Abuses Linked To The Activities Of Pmscs', 5th Session of The IGWG On Pmscs (December 2016), Hlm. 13.
} 
1945, dapat terlihat bahwa dalam pelaksanaan pemenuhan hak-hak yang disebutkan di pasal-pasal sebelumnya, tiap warga negara memiliki kewajiban untuk menghormati hak asasi orang lain, sekalian menjalankan hak asasinya sendiri tanpa mengganggu hidup atau hak asasi orang lain untuk menimbulkan kehidupan yang tertib dan damai dalam bermasayarakat dan bernegara. Dalam Ayat kedua dari Pasal tersebut, dinyatakan bahwa tiap-tiap orang juga harus memperhatikan pembatasan atau limitasi dari pemenuhan atau pengaplikasian hak-haknya yang tersedia dalam undang-undang.

Setelah adanya UUD 1945, akan dibahas Undang-Undang Nomor 39 Tahun 1999 tentang Hak Asasi Manusia ("UU HAM"). Dimana, di dalamnya diperjelas lagi akan hak-hak asasi yang tertuang dalam UUD 1945. Negara juga berkewajiban untuk menyediakan halhal yang semestinya ada dalam penegakan HAM. Seperti, hakim yang adil dan imparsial, proses yang cepat dan sederhana dalam pengadilan, dan tentu biaya Komisi Nasional Hak Asasi Manusia ("KOMNAS HAM") yang dibebankan sepenuhnya kepada Anggaran Pendapatan dan Belanja Negara. Sampai dengan tahun 2000, Indonesia pun mengeluarkan Undang-Undang Nomor 26 Tahun 2000 Tentang Pengadilan Hak Asasi Manusia ("UU Pengadilan HAM"). ${ }^{35}$ UU Pengadilan HAM menjelaskan secara umum kedudukan dan kewenangan suatu pengadilan HAM. UU Pengadilan HAM bekerja dengan baik untuk menitikberatkan tanggung jawab negara Republik Indonesia pada penegakan HAM melalui system pengadilan yang bertujuan khusus untuk mengadili pelanggaran-pelanggaran HAM (special court). ${ }^{36}$

\footnotetext{
35 Pasal 18, Undang-Undang Nomor 26 Tahun 2000 Tentang Pengadilan Hak Asasi Manusia.

36 Adriaan Bedner, 'Rebuilding the Judiciary in Indonesia: The Special Courts Strategy', 01 University of Leiden Journal of Comparative Law Review 13 (1991), hlm. 234.
}

Berdasarkan teori tersebut diatas, maka Penulis akan menguraikan kebebasan berekspresi dalam beberapa poin yakni sebagai berikut :

a. Kebebasan berekspresi apabila ditinjau menurut hukum Hak Asasi Manusia

Kebebasan berekspresi secara harafiah merupakan kemerdekaan individu dalam berekspresi, menyampaikan isi pikiran dan hati nuraninya tanpa dipengaruhi atau ditekan oleh pihak lain. ${ }^{37}$ Apabila mengacu pada Undang-Undang Nomor 9 Tahun 1998 tentang Kemerdekaan Menyampaikan Pendapat di Muka Umum ("UU Kemerdekaan Pendapat") merupakan hak yang kebebasannya dijamin oleh konstitusi kita. Kebebasan ini meliputi kebebasan untuk menyampaikan isi pikiran secara lisan, tertulis, bebas dan bertanggung jawab. Adapun pengaturan 'kebebasan' tersebut sejatinya sejalan dengan Pasal 19 DUHAM yang pada intinya menyatakan bahwa individu berhak atas kebebasan untuk menerima dan mengeluarkan pendapat tanpa gangguan serta untuk mencari, menerima dan menyampaikan keterangan.

Dalam system hukum nasional Indonesia tersedia beberapa pembatasan pada Hak Kebebasan Berekspresi yang disebut dalam UU Kemerdekaan Pendapat. Pasal 6-nya menyatakan bahwa tiap warga negara yang berniat untuk melakukan penyampaian pendapat di muka umum berkewajiban untuk menghormati orang lain, hukum norma moral yang berlaku dalam masyarakat, dan ketertiban umum. Selagi Polisi Republik Indonesia, yang akan menerima laporan jika adanya penyampaian pendapat di muka umum, berkewajiban untuk menghormati hakhak individu yang menyampaikan pendapat, hak asasi manusia secara keseluruhan, dan menyelenggarakan pengamanan sebagaimana mestinya.

\footnotetext{
${ }^{37}$ W.J.S Poerwadirminta, Kamus Umum Bahasa Indonesia, Balai Pustaka, Jakarta, 1984.
} 
b. Kebebasan berekspresi dan berbagai media ekspresi

Kebbasan berbicara, yang biasanya disamakan dengan kebebasan berekspresi, selalu berusaha untuk mencakup tidak hanya perlindungan kebebasan berbicara secara harfiah semata. Namun, pada kenyataanya sulit untuk menggambarkan bagaimana kebebasan berbicara dihubungkan dalam bentuk bahasa isyarat, piktograf, gambar, film, drama, dll. Namun kesimpulan yang dapat ditarik adalah bahwa semua ekspresi memerlukan tindakan dan tindakan apapun dapat bersifat komunikatif. Kebebasan berbicara atau berekspresi harus dianggap sebagai kebebasan berkomunikasi dan bahwa tidak ada batasan apriori pada media komunikasi yang meliputi kebebasan tersebut. ${ }^{38}$

Negara harus bertindak aktif dalam memberikan perlindungan yang diperlukan dalam melindungi pengguna media khususnya kaum minoritas supaya menerima informasi yang ada. Kemudian dengan perkembangan teknologi yang ada diharapkan juga negara dapat meminimalisir kemungkinan adanya monopoli dan objektifitas media dalam bidang penyiaran. Indonesia dalam hal ini, masih dianggap keterbeakangan dalam objektifitas media, menurut Amnesty International, Indonesia masih menempati salah satu posisi terbawah dalam objektifitas dan kepemilikan media terhadap pemegang kekuasaan atau pemerintah.

Adapun kontrol dalam kebijakan penyiaran dan pengawasannya diakukan oleh Komisi Penyiaran Indonesia atau disingkat dengan KPI. Adanya pengawasan media yang dilakukan oleh lembaga ini mencerminkan bahwa adanya pembatasan-pembatasan yang hendak diterapkan dari adanya kebebasan berekspresi. Hal ini dilaksanakan guna untuk menjaga

38 Jed Rubenfeld, 'The First Amendment's Purpose', 53 Stanford Law Review 767 (2001), hlm. 233. ketertiban dan keutuhan moral masyarakat. Akan tetapi, banyak sarjana yang mengatakan bahwa sensor dalam suatu media yang dilakukan dan ditegakkan oleh pemerintah dapat menjadi slippery slope dalam pemberlakuannya, dikarenakan pemerintah dapat memberlakukan peraturan atau hukum positif semenamena dan secara tidak langsung atau langsung sekalipun dapat membatasi merusak kebebasan berekspresi masyarakat sampai jenjang yang tidak bisa diperbaiki lagi (to an irreparable extent).

c. Kebebasan berekspresi sebagai hak dari individu

Sebagai konsekuensi logis dari adanya hak kebebasan berekspresi, maka hal tersebut merupakan hak dari individu A yang mengeluarkan ekspresi tersebut (contoh: penyampaian pidato). Kemudian, ketika pemerintah mengancam individu A tersebut dengan sanksi apabila individu tersebut memberikan informasi atau mengekspresikan informasi tertentu kepada individu $B$, hal ini adalah pelanggaran hak daripada individu A untuk berekspresi.

Menghubungkan pembicaraan diatas berkaitan dengan teori natural rights, maka sejatinya kebebasan berekspresi sebagai hak dari individu merupakan hak yang melekat dalam diri individu sebagai hak yang bukan diberikan oleh institusi yang lebih tinggi daripadanya, namun semata-mata merupakan miliknya dalam konteks kodratnya sebagai seorang manusia. Namun, hak tersebut memiliki penyambung atau penyanding menurut beberapa sarjana. Selain hak individu yang menyatakan pendapat atau berekspresi (active rights), ada juga hak bagi pendengar atau penerima stimulant pendapat/ekspresi (passive rights).

Hal yang barusan dikemukakan dapat mempersulit penalaran beberapa calon sarjana hukum. Namun, jika menyambung dengan konsep kewajiban dalam hak asasi manusia, yakni, untuk 
menjaga dan menghormati hak asasi manusia orang lain, dapat disimpulkan bahwasanya kebebasan untuk berekspresi dapat dan memang dibatasi oleh hak-hak orang lain. Hal ini paling sering terjadi dalam halnya menjaga ketertiban umum. Negara, yang berkewajiban untuk menyelenggarakan keamanan, perdamaian dan ketertiban untuk khalayak ramai, berkewajiban untuk menumpas atau (lebih tepatnya) membatasi hak orang untuk berekspresi dan berpendapat apabila pemenuhan hak tersebut akan menghasilkan gangguan pada hak-hak orang lain di seperti hak seorang individu untuk merasakan keamanan dalam hidup. Ini merupakan suatu paradoks dalam penjalanan dan pemenuhan hak asasi yang jatuh pada sifat dasar kodrati suatu manusia.

\section{KESIMPULAN}

Dari semua pernyataan diatas, dapat disimpulkan bahwa selain sifat abstrak dari ekspresi itu sendiri dalam halnya etimologi. Adanya sifat abstrak yang tertera pada pengaplikasian hak untuk ekspresi tersebut. Dimana, perlu diadakannya Analisa berkaitan aspek yuridis praktis (human rights due diligence) yang berupaya untuk mengkonkritkan hal yang abstrak yang dihadapi oleh ahli-ahli hukum, aspek etimologi ekspresi itu sendiri untuk mengetahui kebutuhan dasar manusia untuk mengekspresikan diri, Batasanbatasan tanggung jawab negara dalam penegakkan hak asasi berekspresi, media berekspresi untuk dipakai seorang individu sebagai sarana ia menyatakan pendapat serta regulasi dan norma yang mengatur, dan sebagai bentuk hukum perkembangan, suatu hak berekspresi yang bersifat komunal, dikarenakan diksi dari 'hak asasi manusia' dapat diartikan bahwa manusia bukanlah saja sebagai seorang individu, akan tetapi, juga sebagai sekelompok orang atau bahkan satu ras manusia yang mengemban hak dan kewajiban berekspresi sekalipun.

Pada dasarnya, suatu kebebasan bereskpresi merupakan hak dari semua anggota masyarakat, maupun itu seorang individu ataupun kelompok. Namun, perlu diketahui pula, bahwa Batasanbatasan riil-nya juga diadakan untuk memenuhi fungsi negara dalam menjalankan ketertiban umum dan pemeliharaan moral masyarakat. Oleh karena itu, diperlukan banyak kajian dalam hal-nya pemenuhan hak asasi manusia dalam berekspresi, sebagai tindak lanjut pemerintah menjalankan tanggung jawabnya yang tidak bias dan objektif.

\section{A. BUKU}

\section{DAFTAR PUSTAKA}

Allen Buchanan dan David Golove, The Philosophy of International Law, dalam Oxford

Handbook of Jurisprudence and Philosophy Law, oleh J. Coleman, 2002.

Masyhur Effendi, Dimensi dan Dinamika Hak Asasi Manusia dalam Hukum Nasional dan

Internasional, 1994: Ghalia Indonesia, Jakarta.

\section{B. JURNAL}

Alexander Hamilton, The Farmer Refuted, dalam Henry Cabot Lodge, ed., The Works of

Alexander Hamilton (New York: G.P. Putnam's Sons, 1904) Volume. 1.

Centre for Law and Democracy, Pembatasan Kebebasan Berekspresi : Sebuah Standar dan

Prinsip, Latar Belakang Pertemuan yang diselenggarakan oleh UN Special Reporteur Expression.

tentang Freedom of Opinion and

Factsheet of Right to Freedom of Expression, Human Rights and Discrimination Commissioner- ACT Human Rights Commission. Dapat diakses melalui 
https://hrc.act.gov.au/wpcontent/uploads/2015/03/Secti on-16-Right-to-Freedom-ofExpression.pdf

Jack Donnely, Universal Human Rights in Theory and Practice, 2003, Cornell University Press,
Itchaca and London.

Kovenan Internasional tentang Hak-Hak Sipil dan Politik, 16 Desember 1966, Perserikatan

Bangsa-Bangsa, Treaty Series, Vol. 999. 